\title{
Sistem Pertukaran Orang Sasak dalam Prosesi Sorong Serah Ajikrame
}

\section{Ahmad Fauzan}

Universitas Islam Negeri Mataram

Naskah diterima 5 Nov 2018, direvisi 12 Des 2018, disetujui 25 Jan 2018

Abstract Sasak people Trasaksionalisme we can find on the procession merariq which there are series of processions such as ajikrama handover , we make it as the object in "social exchange". So in the procession of Sasakajikrama handover is a binding kinship transaction between the family of the prospective groom and bride. Keyword: ajikrama handover, merariq (marriage), exchange, transaksionalime, sasak people

Keyword: Slide the transfersajikrame, merariq, Exchange, transaksionalisme, Sasak people.

Abstrak Trasaksionalisme orang Sasak dapat kita temukan pada prosesi merariq yang didalamnya terdapat beberapa rangkaian prosesi seperti sorong serah ajikrama yang kita jadikan- obyek—dalam "pertukaran sosial". Sehingga dalam prosesi sorong serah ajikrama orang Sasak ini merupakan transaksi pengikat kekerabatan antara keluarga calon pengantin laki-laki dan keluarga calon pengantin perempuan.

Kata kunci: Sorong serah ajikrame, merariq, pertukaran, transaksionalisme, orang Sasak.

\section{A. PENDAHULUAN}

Sorong serah ajikrama merupakan suatu prosesi adat yang dilakukan oleh pihak keluarga calon mempelai laki-laki terhadap pihak keluarga calon mempelai perempuan dalam suatu upacara pernikahan dalam masyarakat Sasak. Menurut Azhardalam Febrian Abbas"sorong" artinya menyodorkan dan "serah" artinya menyerahkan, sorong serah artinya serah terima. Sedangkan "aji" 
artinya nilai atau harga dan "krama" artinya aturan, ketetapan atau kebiasaan. Oleh karena itu, "sorongserah ajikrama" yang artinya "serah terima suatu harga atau nilai yang sudah ditetapkan". Dengan kata lain "sorong serah ajikrama" disini berarti" serah terima (pembayaran berupa uang oleh pihak mempelai laki-laki kepada mempelai perempuan dalam suatu proses pernikahan) yang manajumlah/nominal uang yang dikeluarkan sesuai dengan jumlah/ nominal yang sudah ditetapkan oleh masyarkat setempat".

Selanjutnya, Sorong Serah Ajikrama dapat kita jumpai pada saat adanya sebuah prosesi merarik dalam masyarakat Sasak. Sebagaimana masyarakat Sasak telah sepakat memberikan arti dari kata Sorong Serah Ajikrama sebagai bentuk "acara serah terima nilai adat yang telah dibiasakan". Selain itu, istilah Ajikrama juga dapat dimaknai dari kata Aji yang berarti bapak dan Krama yang berarti adat. Sehingga, Ajikrama diartikan sebagai bapaknya adat. Dengan kata lain, makna acara Sorong Serah Ajikrama merupakan "prosesi wisuda atau peresmian atas kelahiran keturunan dari sebuah perkawinan".

Ada juga yang mengatakan ajikrama itu sebagai "aji Suci" dan mengartikan "aji" berarti harga dan "Suci" berarti membersihkan. Namun, makna yang diberikan di atas dilihat dari nilai ajikrama, dapat dipadukan menjadi satu batasan pengertian "ajikrama" yaitu suatu kesepakatan keseluruhan warga adat suatu wilayah yang mempunyai kesatuan hukum yang tetap sebagai lambing penyucian nilai kemanusiaan (Depdikbud, 1994: 16 via Febrian Abbas, tt; ejurnal.iainmataram.ac.id).

Berangkat dari berbagai definisi di atas dapat disimpulkan bahwa sorong serah aji krama berarti: menyerahkan sesuatu yang biasanya berupa (kepeng) dengan jumlah tertentu, ditambah dengan barang-barang lain seperti kain dan lain-lain, yang secara keseluruhan dinilai, nilainya harus berjumlah sama dengan jumlah aji krama pihak wanita.

Sorong Serah merupakan tradisi turun temurun dari nenek moyang dan sudah melekat dalam masyarakat Sasak (bersifat 
aturan yang dipedomani), bahkan beberapa kalangan masyarakat baik itu tokoh agama dan tokoh masyarakat adat itu sendiri menyatakan bahwa jika tidak melaksanakan upacara adat ini akan menjadi aib bagi keluarga dan masyarakat setempat. Tradisi seperti ini berlaku hampir di seluruh lapisan masyarakat Sasak.

Kajian Sorong Serah Ajikrama ini merupakan gejala-gejala sosial yang bentuknya "saling tukar menukar hadiah dan pemberian" yang tersebar luas dalam masyarakat Sasak, dan apa yang kita lihat dari gejala sosial tersebut ialah memperlihatkan pemahaman mengenai fungsinya dalam artikulasi keteraturan sosial, tentunya memiliki keterkaitan mengenai transaksionalisme dan strukturalisme.

Jadi, segala bentuk pemberian selalu dibarengi dengan sesuatu pemberian kembali atau imbalan. Dengan demikian, maka yang ada bukanlah hanya pemberian oleh seseorang kepada yang lainnya, tetapi suatu tukar-menukar pemberian yang dilakukan oleh dua orang atau kelompok yang saling memberi dan mengimbangi dalam Sorong Serah Ajikrama (Suparlan, 1992).

Tukar menukar pemberian seperti Sorong Serah Ajikrama yang dilakukan oleh orang Sasak pada saat prosesi merarik, sebagaimana Marcel Mauss mengatakan bahwa "pemberian hadiah yang dilakukan oleh seorang suami kepada istrinya haruslah dilihat sebagai suatu imbalan atas pelayanan seksual yang diberikan oleh si istri kepada suaminya" (Suparlan, 1992:xviii). Sehingga pemberian itu sendiri sebenarnya dapat dilihat sebagai suatu transaksi yang berlaku di antara si pemberi dengan si penerima.

Sebagaimana yang diperlihatkan oleh Malinowski juga: "bahwa semua bentuk transaksi berada dalam suatu garis hubungan yang berkesinambungan yang di satu kutub pemberian itu bercorak murni, tanpa tuntutan imbalan, dan di kutub lainnya bercorak pemberian yang harus diimbali" (dalam Suparlan, 1992).

Asumsi yang pertama dari "pertukaran" dalam prosesi sorong serah ajikrama orang Sasak ini dapat kita lihat sebagai "transaksi 
pengikat kekerabatan" antara keluarga calon pengantin laki-laki dan keluarga calon pengantin perempuan.

\section{B. METODE PENELITIAN}

Metode kualitatif dalam penelitian sistem pertukaran orang sasak dalam prosesi sorong serah ajikrame studi kasus pada masyarakat suku Sasak di Lombok. Pengumpulan data dilakukan melalui observasi, wawancara, dan studi dokumentasi. Kemudian menganalisis menggunakan teori fungsionalisme-struktural Barth. Demikian hasil penelitian bahwa, sorong serah ajikrama merupakan gejala sosial bentuknya saling tukar menukar hadiah dan pemberian tersebar luas dalam masyarakat Sasak, gejala sosial tersebut memperlihatkan pemahaman mengenai fungsinya dalam artikulasi keteraturan sosial, memiliki keterkaitan mengenai transaksionalisme dan strukturalisme.

\section{HASIL DAN PEMBAHASAN}

\section{Selayang Pandang Sistem Perkawinan Masyarakat Sasak}

Dalam kehidupan masyarakat Lombok, perkawinan merupakan salah satu tahapan hidup atau life cycle yang sangat penting bagi keberlangsungan hidup kekerabatan. Melalui perkawinan seorang anak laki-laki Sasak akan memperoleh hak-hak di samping kewajiban-kewajiban tertentu. Baik dalam lingkungan kekerabatan atau kadang waris maupun sebagai anggota masyarakat atau krama paer. Dengan demikian, perkawinan atau pernikahan bukan hanya sekedar cara untuk mengatur kehidupan berumah tangga dan reproduksi keturunan, tetapi lebih dari itu bahwa perkawinan juga merupakan jalan untuk menuju perkenalan antara satu kaum dengan kaum yang lain yang akan membawa kepada sikap saling menolong antara dua belah pihak (Geertz, 1983 via Kumbara, 2008: 102).

Di Lombok, sistem perkawinan yang dianggap ideal adalah perkawinan antara anak laki-laki dengan anak perempuan saudara laki-laki ibunya atau cross cousin assimetris. Menurut adat, hubungan seperti ini harus dipelihara terus. Para orang tua 
senantiasa menganjurkan putra-putrinya supaya kawin dengan saudara sepupunya atau keluarga yang masih satu keturunan atau buyut atau seke dan paput. Lebi-lebih lagi apabila hubungan kekerabatan ke samping sudah mencapai lebih dari derajat tiga, maka setiap orang tua Sasak akan mengupayakan agar anak mereka bisa kawin dengan orang yang dianggap masih ada hubungan kekerabatan, baik atas dasar hubungan darah maupun melalui perkawinan sebelumnya. Hal ini dimaksudkan, disamping karena alasan mempertahankan keturunan, mempertahankan harta pusaka agar tidak jatuh ketangan orang lain yang tidak sedarah, juga untuk mempererat hubungan kekerabatan yang sudah dirasa semakin jauh. Adat perkawinan dengan sepupu atau cross cousin secara idogami atau antarkerabat sedarah di Lombok, hingga kini masih relatif bertahan terutama di kalangan bangsawan Sasak di wilayah-wilayah tertentu. Hal ini terjadi, karena perkawinan dengan sepupu dianggap sebagai pola yang ideal. Skema kekerabatan (Cross Cousin) dari Satu Keturunan dari Laki-laki/ Perempuan yang melakukan Perkawinan Sesama Pisa' (sepupu).

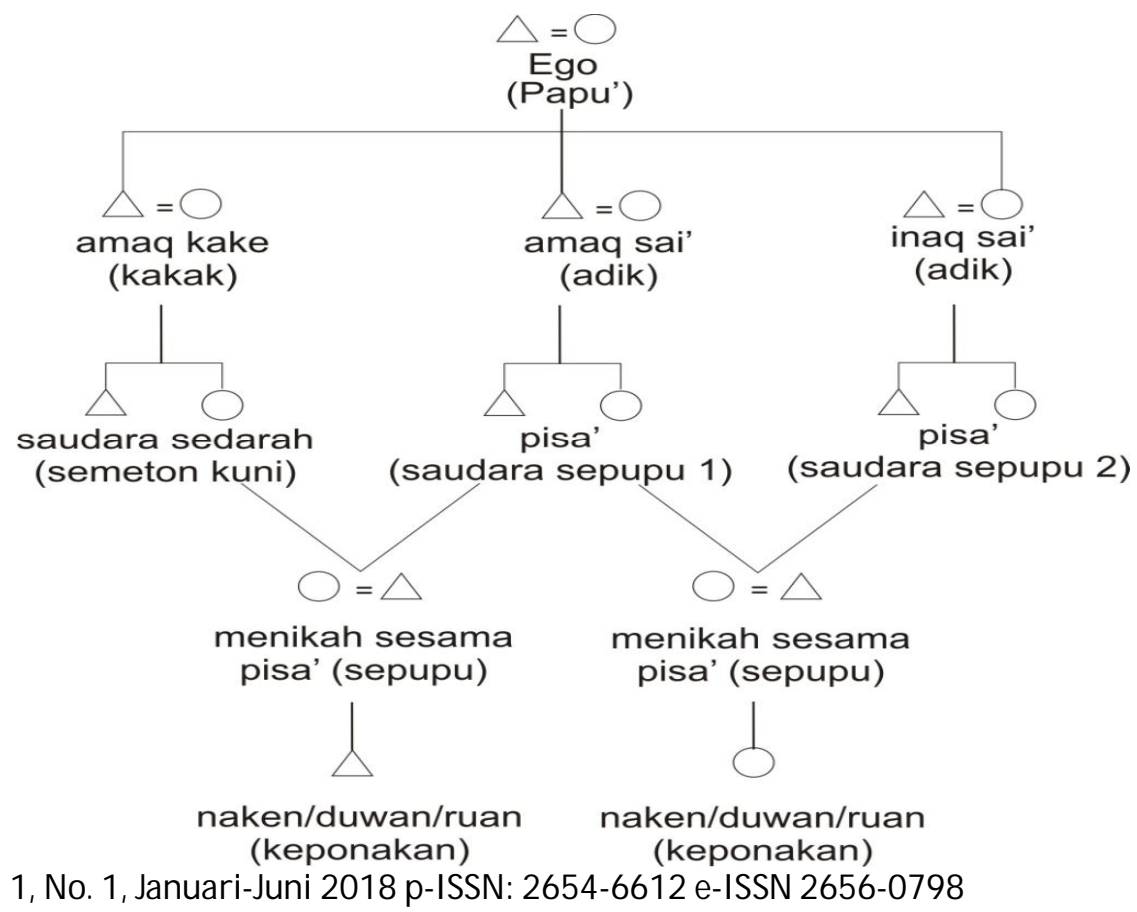


Sebagaimana yang ditemukan Kumbara (2008: 104) dalam penelitiannya, di desa-desa tertentu di Lombok Timur, seperti Pademare, Kotaraja, wilayah Sembalun, Sikur dan di Lombok Tengah, seperti Kateng, Batu Jai, Mantang, Sengkol serta di wilayah Lombok Barat, seperti Gerung dan Kuripan, yang sebagian para orang tua bangsawan atau perwangsa secara ketat melarang anak gadisnya kawin dengan pemuda yang dianggap tidak sederajat, terutama dari keluarga bukan bangsawan atau jajarkarang. Bila larangan itu dilanggar, maka si gadis akan dibuang sebagai bagian dari keluarga mereka. Akibatnya, dibeberapa desa tersebut banyak gadis yang terpaksa tidak kawin atau kawin dalam usia relatif tua karena tidak mendapatkan jodoh sesuai dengan keinginannya. Di sisi lain, masuknya pengaruh pemikiran modern, pergaulan kota dan pendidikan, dewasa ini semakin banyak para pemuda yang kawin dengan gadis-gadis lain yang bukan sepupunya atau secara eksogami dan atau kawin bukan atas dasar pilihan orang tuanya.

Menurut adat dan kebiasaan yang berlaku di Lombok. Misalnya dikenal adanya dua jenis perkawinan, yaitu dengan cara adat meminang yang dalam bahasa lokal sering disebut ngelamar, dan adat merariq. Praktek kawin dengan perjodohan di daerah-daerah pedesaan di Lombok sejak tahun 1970-an sudah mulai berkurang dan praktek merariq atau melarikan, dianggap lebih ideal dari bentuk perjodohan.

Dari kedua adat kawin, di Lombok dijumpai bahwa tradisi merariq atau melarikan lebih populer dan lebih disukai oleh calon mempelai, utamanya dari pihak keluarga bukan bangsawan atau jajarkarang. Menurut informasi, hal itu di karena-kan para orang tua laki-laki takut dan khawatir apabila lamarannya ditolak oleh pihak keluarga perempuan; dan jika hal demikian terjadi akan menjadi aib bagi keluarganya. Di pihak lain, bagi keluarga perempuan meminta langsung kepada seorang ayah atas anak perempuannya untuk dinikahi, apalagi dilakukan oleh orang yang dianggap status sosialnya tidak sederajat, juga dapat dianggap sebagai penghinaan terhadap dirinya, anak wanitanya, dan 
keluarganya (Bartholomew, 2001:195). Hal ini berlaku terutama pada keluarga-keluarga bangsawan atau di daerah desa-desa tertentu. Hal yang sering mereka nyatakan adalah "permintaan anak perempuan oleh orang yang tidak sederajat atau tidak ada hubungan keluarga; agaknya seperti meminta "seekor ayam"saja".

Atas dasar alasan-alasan tersebut, maka praktek kawin merariq di Lombok umumya menjadi pilihan yang dominan. Namun demikian, kawin merariq pada pasangan yang berbeda latar belakang status sosialnya, khususnya bila gadisnya berasal dari keluarga bangsawan dan laki-lakinya dari keluarga biasa (jajarkarang) sering memunculkan konflik di seputar proses perkawinan tersebut.

Perkawinan ngelamar atau sesukaq tutuoaq terbagi menjadi dua macam, yaitu dengan sepengetahuan pihak si anak dan tanpa sepengetahuan si anak. Pada sesukaq tutuoaq yang pertama biasanya diawali dengan pihak orang tua menanyakan terlebih dahulu kepada pihak si anak apakah anaknya mencintai calon pilihan orang tuanya atau tidak. Jika kemudian diketahui bahwa si terune dan si dedare memang saling mencintai, maka selang beberapa waktu barulah orang tua si laki-laki mengadakan kunjungan ke rumah si gadis yang biasanya adalah temanya sendiri untuk mengadakan perundingan. Tahap awal inilah yang termasuk dalam proses ngelamar. Sebaliknya, sesukaq tutuoaq dengan tanpa sepengetahuan si anak biasanya orang tua mengamati terlebih dahulu gerak-gerik anaknya yang telah diketahui menjalin hubungan dengan lawan jenisnya. Setelah mengetahui bahwa anaknya memang saling mencintai, maka kemudian di antara orang tua langsung mengadakan perundingan . akhirnya, setelah sampai pada kata putus antara kedua orang tua dilangsungkanlah perkawinan anak-anaknya. Model perkawinan sesukaq tutuoaq yang tanpa sepengetahuan si anak saat ini sudah sangat jarang dilakukan, namun untuk keluarga-keluarga tertentu dan wilayah tertentu di Lombok masih tetap eksis. Perbedaan yang cukup mendasar antara sesukaq tutuoaq dengan merariq ialah pada proses yang disebut selabar. Kalau pada sesukaq Vol. 1, No. 1, Januari-Juni 2018 p-ISSN: 2654-6612 e-ISSN 2656-0798 
tutuoaq,selabar tidak menjadi suatu hal yang penting untuk dilakukan, sementara pada merariq, selabar merupakan sesuatu yang harus dilakukan pada tahap awal, yaitu sesudah si laki-laki membawa lari si gadis (Kumbara, 2008: 105-106).

Desa-desa di Lombok secara umum dengan proses pencarian jodoh dimulai ketika para lelaki menginjak remaja dan para dedare mulai diincar oleh terune. Saat itu sering sang dedare sekalipun telah menetapkan pujaannya, namun dia tetap akan berusaha memberi sambutan yang sama hangatnya kepada setiap terune karena si dedare tidak ingin membuat terune yang datang berkunjung menjadi tersinggung atau kecewa. Kunjungan para terune ke rumah dedare pada masa mencari simpatik, baik si gadis pujaannya maupun orang tua si gadis di sebut midang. Pada saat midang inilah para jejaka akan menunjukkan rasa cinta dan perhatian dengan cara masing-masing. Ada yang menunjukkan dengan benda-benda pemberian yang disebut pereweh atau pembugi atau pengubuk. Ada pula yang menunjukkan perhatian dengan cara membantu orang tua si dedare mengerjakan pekerjaan di sawahnya.

Secara tradisi batasan yang diberikan masyarakat kepada seorang dedare untuk boleh merariq, yaitu minimal si gadis telah tujuh tahun dari masa haid pertama atau sekitar 21 tahun. Sebaliknya, masa pacaran yang dianggap ideal sebelum melangsungkan perkawinan ialah antara tiga bulan sampai tiga tahun. Dengna proses itu, diangggap masing-masing bisa dan mempunyai kesempatan untuk mengetahui segala sifat-sifat kebaikan dan keburukan yang dimilikinya sehingga nantinya bila sudah berumah tangga, jangan sampai terjadi perceraian. Namun, secara empirik menurut aparat desa setempat, masalah perkawinan dalam usia muda dan tingginya tingkat perceraian merupakan masalah yang dihadapi masyarakat, baik di Kuranji maupun Lombok pada umumnya. Di duga bahwa tingginya tingkat perceraian itu terkait dengan kondisi kemiskinan yang relatif tinggi dan rendahnya tingkat pendidikan rata-rata penduduk di wilayah Lombok secara umum. 
Konsep dasar merariq adalah di samping memberi kesempatan kepada para wanita untuk menentukan sikap dan pilihan dengan pertimbangan dan pemikiran yang matang, juga memberi peluang yang sama bagi perjaka untuk mempersunting wanita yang disukainya. Bagi calon pengatin pria tindakan merariq dipandang sebagai ujian terhadap keberanian atau kejantanan dan cermin kualitas personal pria bersangkutan karena kawin merariq cukup mengandung resiko. Merariq pada siang hari di samping dianggap telah melanggar adat juga secara sosial melukiskan sifat-sifat pengecut laki-laki. Pelanggaran terhadap adat merariq akan mendapat sanksi adat pada acara sorong serah aji krama.

Proses "kawin lari" atau merariq dilakukan melalui perantara yang biasanya dari pihak keluarga laki-laki yang telah dipercaya atas nama pacar laki-laki yang merancang untuk bertemu di suatu tempat yang telah direncanakan. Di sana sang calon pengantin bersama dengan laki-laki lain telah menunggu untuk selanjutnya melarikan sang gadis ke tempat keluarga laki-laki yang dihormati. Biasanya si perempuan calon pengantin dibawa ke tempat paman laki-laki. Setelah sampai di rumah kerabat atau paman laki-laki dan pihak tuan rumah itu setuju atas pelarian itu, maka salah seorang perwakilan kerabat laki-laki akan melapor kepada aparat desa bahwa Si A dan Si B telah kawin dan sekarang ada di rumah pihak laki-laki. Peristiwa ini disebut mesejati.

Secara adat, kedua calon pengantin tidak boleh tidur bersama atau harus tidur di tempat terpisah sampai tahapan adat dilalui. Sehari setelah pelarian si gadis pihak keluarga perempuan untuk mempermaklumkan kepada keluarga dan lingkungan bahwa anak gadis si A sudah kawin dengan laki-laki si B dan memberikan secara lengkap identitas keluarga pihak laki-laki . proses ini disebut dengan selabar. Untuk menghindari hal-hal yang tidak diinginkan karena emosi dan ketidaksetujuan orang tua perempuan, biasanya utusan ini diterima oleh perwakilan keluarga pihak perempuan. Selang beberapa hari, umumnya 2-3 hari berikut, pihak keluarga laki-laki mengutus perwalian (tuan guru dan tokoh adat) ke rumah pihak perempuan untuk Vol. 1, No. 1, Januari-Juni 2018 p-ISSN: 2654-6612 e-ISSN 2656-0798 
membicarakan dan minta wali orang tua perempuan dalam acara akad kedua calon pengantin tersebut. Peristiwa ini disebut dengan baitwali atau ngendeng wali. Dalam syariat Islam, wali merupakan rukun nikah yang harus dipenuhi demi sahnya sebuah perkawinan. Setelah bait wali itu, acara dilanjutkan dengan rebak pucuk, yaitu menyampaikan pesan atau amanat untuk menanyakan kesiapan pihak keluarga perempuan dalam acara selanjutnya. Menindaklanjuti proses tersebut pihak laki-laki mendatang pihak perempuanuntuk menentukan upacara adat sorong serah sekaligus membicarakan hal-hal yang terkait dengan persyaratan-persyaratan yang akan melengkapi pelaksanaan upacara adat yang disebut dengan ngendeng wali.

Dalam ngendeng wali ini akan terjadi pembicaraan dan tawarmenawar anatara pihak keluarga pengantin perempuan dengan wali atau penghulu pihak laki-laki tentang berapa besar beban adat, maskawin atau mahar yang disepakati yang harus dibayar pihak laki-laki dengan tetap memperhatikan musyawarah dan kebersamaan. Besar kecilnya beban adat biasanya berhubungan dengan latar belakang keluarga perempuan apakah dia dari keluarga bangsawan atau pemenak ataukah orang biasa atau jajarkarang. Jika dia pemenak, maka secara cultural dia memiliki nilai sorong serah yang lebih tinggi daripada golongan jajarkarnag. Aji krama yang dibayarkan pihak laki-laki ke pihak keluarga perempuan tidak diterima oleh ornag tua mempelai perempuan, tetapi dibagikan kepada kerabat dan para undangan yang hadir, yang dipimpin oleh pamong desa serta disaksikan oleh tokoh adat dan tokoh agama, terutama tuan guru. Terdapat variasi yang cukup mencolok antar desadalam penentuan besarnya nilai aji krama. Untuk kelompok bangsawan tertinggi atau raden biasanya bernilai dua ratus, bangsawan menengah bernilai seratus enam puluh enam, dan orang biasa atau jajarkarang, bernilai tiga puluh tiga. Sedangkan untuk kelompok pajak bernilai tujuh belas. Akan tetapi, menurut informan setempat untuk golongan yang disebut terakhir sudah tidak ada lahi di Lombok saat ini. 
Di desa Kuranji, nilai aji krama untuk bangsawannya adalah enam puluh karena di desa ini tidak terdapat bangsawan setingkat raden atau hanya ada bangsawan tingkat menengah atau lalu. Sebaliknya, untuk orang biasa atau jajarkarang aji krama bernilai "tiga puluh tiga samas" atau sama dengan tiga puluh tiga, dan tidak ada yang bernilai tujuh belas.

Selain berupa uang yang jumlahnya sesuai dengan niali aji krama yang disepakati kedua belah pihak, aji krama juga diwujudkan dalam bentuk benda mati ataupun hidup, umumnya berupa sapi. Secara keseluruhan aji krama itu terdiri atas kain tenun, keris, sawah, dan uang tunai. Banyak sedikitnya jumlah benda yang dibayarkan itu sering berkorelasi dengan tingkat kemampuan pihak laki-laki, dan hasil negosiasi atau kesepakatan antara kedua belah pihak keluarga mempelai.

Menurut keterangan tokoh masyarakat setempat, penentuan nilai aji krama tersebut sesungguhnya bukanlah mengacu pada nilai nominal komersial an sich saja, tetapi juga sarat dengan kandungan makna filosofis dan simbolik. Dalam makna simbolik, kain artinya kesanggupan suami untuk memenuhi kebutuhan sandang kepada istrinya. Keris bermakna kemampuan suami untuk memenuhi kebutuhan akan keamanan rumah tangganya, kesanggupan suami untuk melindungi istrinya. Sawah dan sapi artinya kesanggupan suami untuk memenuhi kebutuhan belanja istri sehari-hari. Sebaliknya, secara social upacara sorong serah aji krama berfungsi sebagai media komunikasi kepada masyarakat atas perkawinan antara kedua mempelaitersebut, sebagai media untuk memperbaiki keretakan hubungan yang terjadi sebelumnya, terutama pada pihak keluarga perempuan bangsawan yang kawin dengan laki-laki (jajarkarang), dan selanjutnya mempererat hubungan persaudaraan kedua belah pihak atas perkawinan tersebut.

Menurut kepercayaan setempat, kalau misalnya sepasang pengantin oleh orang tuanya tidak diupacarakan secara adat, maka pasangan pengantin itu tidak akan pernah bahagia dan aman tenteram dalam kehidupan rumah tangganya. Di samping itu, Vol. 1, No. 1, Januari-Juni 2018 p-ISSN: 2654-6612 e-ISSN 2656-0798 
menurut norma social apabila pasangan pengantin itu tidak melaksanakan upacara sorong serah, orang bersangkutan juga akan mendapat cemohan dari lingkungannya, karena dianggap tidak menghargai adat atai ndeq tawang kon adat. Implikasinya, setiap keluarga yang punya gawe merariq atau melangsungkan pernikahan berusaha utnuk melangsungkan upacara tersebut.

Setelah akad nikah dilangsungkan keluarga pengatin laki-laki mengajak orang tua mempelai perempuan atau sumbah untuk bersama-sama mencari hari baik dalam rangka mengadakan acara tasyakuran atas berlangsungnya pernikahan anak mereka. Acara tasyakuran ini berlangsung di dua tempat, yaitu di rumah pengantin pengantin laki-laki dan di rumah pengantin perempuan. Setelah acara tasyakuran itu berakhir kemudian anggota keluarga pihak laki-laki yang diiringi dengan rombongan muda-mudi berpakaian seragam adat kebesaran Sasak menuju ke rumah mempelai perempuan, yang disebut dengan nyongkolan atau nyondol. Dalam acara nyongkolan ini pengantin laki-laki dan rombongan akan diiringi dengan kesenian rakyat Sasa, seperti Kecimol, Gendang Beleq atau Dogdag. Sementara di pihak perempuan juga sibuk untuk menyambut kedua mempelai yang biasanya juga diadakan kesenian serupa. Sebelum kedua mempelai yang biasanya juga diadakan masuk ke rumah mempelai perempuan diadakan acara sorong serah aji krama adat dari pihak laki-laki ke pihak perempuan. Bagi orang Sasak, sorong serah aji krama merupakan proses adat perkawinan yang sangat penting dan dipandang memiliki nilai yang sakral dan nilai filosofi tinggi. Dengan demikian, bila prosesi ini tidak dilaksanakan, akan merupakan aib bagi keluarga sukubangsabangsa Sasak.

Dalam acara sorong serah aji krama adat tersebut pihak lakilaki diwakili oleh beberapa orang utnuk membawa aji krama adat yang dipimpin oleh seorang juru bicara yang disebut pembayun, sementara dari pihak perempuan dipimpin oleh penemin. Dalam acara ini terjadi dialog panjang lebar anatara pembayun dan penemin dengan mempergunakan bahasa Sasak halus bercampur dengan bahasa Kawi. Isi dialog mereka umumnya berkisar seputar 
perkawinan kedua mempelai sejak pencurian sampai acara nyongkolan dan sering diselingi dengan pantun-pantun jenaka serta nasihat-nasihat kepada kedua mempelai tentang hak-hak dan kewajiban suami-istri dalam mengarungi rumah tangga. Setelah acara sorong serah itu selesai barulah kedua mempelai boleh masuk ke tempat arena nanggep atau pelaminan tersebut. Dengan demikian, sorong serah aji krama mempunyai fungsi untuk memberitahu kepada umum mengenai terbetuknya sebauh keluarga baru yang berdasarkan adat, mempersatukan kedua keluarga dan kerabat yang disebut pegaluh kadang jari, memperluas mata-rantai keluarga. Sebagai akibat dari hal ini, mereka tidak boleh bagi mele atau suka kepada orang lain, atau tidak boleh lagi diganggu oleh orang lain dan sekaligus memperoleh hak-hak serta kewajiban-kewajiban baru sebagai warga yang lebih luas, baik di tingkat gubuk atau kampung, dasan atau dusun, maupun tingkas desa.

\section{Transaksionalisme dalam Sorong Serah Ajikrama}

Transaksionalisme, Studi-studi antropologi mengenai transaksi yang berlangsung pada tingkat individu boleh dikatakan berawal dari pemikiran-pemikiran Fredrik Barth pada akhir tahun 1950an hingga tahun 1960an, dan mencapai titik kulminasinya pada tulisan Barth yang berjudul Models for Social Organization (1966) (dalam Ahimsa-Putra, 2003). Karya yang diakui oleh banyak ahli antropologi sebagai penanda dari paradigm shift (pergantian paradigma) dalam antropologi ini muncul sebagai reaksi Barth atas beberapa kesulitan yang dialaminya di lapangan ketika dia berusaha menjelaskan berbagai fenomena sosial lewat kacamata fungsionalisme-struktural, yang ketika itu merupakan paradigma dominan dalam antropologi (Kapferer, 1976 dalam Ahimsa-Putra, 2003).

Selanjutnya, dalam pandangan Barth bahwa pendekatan fungsionalisme-struktural menyimpan berbagai masalah ketika digunakan untuk menjelaskan fenomena sosial. Pertama, paradigma ini memandang masyarakat sebagai suatu sistem Vol. 1, No. 1, Januari-Juni 2018 p-ISSN: 2654-6612 e-ISSN 2656-0798 
moral, sistem norma-norma, aturan-aturan, yang muncul lebih dulu daripada perilaku. Kedua, analisis fungsionalisme-struktural belum mampu mengungkap "any intervening social processes between the moral injunction and the pattern". Ketiga, pendekatan tersebut memulai kajian tentang masyarakat dan kebudayaan dengan mengasumsikannya sebagai "a structurally integrated whole", sehingga ia tidak dapat menangani atau memahami masalah-masalah perubahan sosial dengan memuaskan. Oleh karena itu, Barth kemudian mengusulkan agar para ahli antropologi memusatkan perhatian pada proses yang mengintegrasikan berbagai unsur pranata dalam masyarakat serta kondisi-kondisi dan proses yang menghasilkan (dan juga tidak menghasilkan) makna-makna yang dimiliki bersama (Barth, 1966 dalam Ahimsa-Putra, 2003).

Apa yang dikemukakan oleh Barth tersebut tidak seluruhnya baru tentu saja. Beberapa ilmuwan sosial sebelum Barth, seperti George Simmel misalnya, bahkan juga Bronislaw Malinowski dan Raymond Firth, yang dikenal sebagai tokoh-tokoh aliran fungsionalisme, sebenarnya sudah mulai mengarahkan perhatian mereka pada proses-proses dalam kehidupan sosial masyarakat yang mereka teliti. Sementara itu ahli-ahli antropologi ekonomi yang berada dalam kubu formalis (Sairin dkk., 2002), juga telah mengemukakan konsep-konsep seperti maksimisasi (maximization), ekonomisasi dan rasionalitas (Burling, 1968 dalam Ahimsa-Putra, 2003: 21), yang pada dasarnya mempunyai titik-titik temu teoritis dengan pandangan Barth. Di sisi lain, ahliahli antropologi dari generasi Fredrik Barth, seperti Clifford Geertz di Amerika Serikat dan Edmund Leach di Inggris juga telah merasakan kelemahan-kelemahan yang sama dari aliran Fungsionalisme-Struktural, dan telah mengusulkan jalan keluar yang kurang lebih sama (Geertz, 1976 dan Leach, ). Bedanya adalah dalam hal ini Barthlah tampaknya yang paling serius memikirkan kelemahan tersebut dan mencoba menawarkan sebuah paradigma baru yang dianggapnya lebih sesuai untuk penelitian antropologi. Pandangan Barth menjadi lebih 
berpengaruh, karena dia juga yang secara konsisten mengembangkan pendekatan yang diusulkannya dan menerapkan dalam beberapa penelitiannya (lihat Barth, 1959a; 1959b; 1963 dalam Ahimsa-Putra, 2003: 21).

Inti dari pendekatan tersebut adalah bahwa analisis antropologi harus processual (prosesual). Artinya, analisis tersebut harus dapat menjelaskan bagaimana aneka-ragam bentuk-bentuk sosial (social forms) seperti misalnya segmentary lineage structure, unit-unit produksi, persekutuan-persekutuan politis dan sebagainya, muncul atau terbentuk. Ini semua hanya dapat dicapai jika analisis antropologi secara eksplisit memusatkan perhatian pada perilaku-perilaku transaksional (transactional behavior) (dalam Ahima-Putra, 2003).

Apa perilaku-perilaku transaksional ini? Tidak lain adalah "sequences of interaction systematically governed by reciprocity" (rangkaian-rangkaian interaksi yang secara sistematis diatur oleh resiprositas, ketimbal-balikan). Jadi pendekatan transaksional antar individu-individu "who are engaged in a series of transactions that evolve over time' (1977: 119). Oleh karena itulah, pendekatan transaksional juga sering disebut sebagai pendekatan interaksional (interactional) (dalam Ahimsa-Putra, 2003).

Dengan paradigma ini perhatian peneliti akan diarahkan terutama pada isi transaksional dari relasi-relasi antarperson, dan analisisnya ditujukan pada "the process by which the parties involved negotiate the 'terms of trade' and attempt to maximize their interest", proses yang dilewati oleh pihak-pihak yang terlibat ketika mereka tawar-menawar 'terms of trade' dan berupaya memaksimalkan keuntungan mereka (Long, 1977: 120 via Ahimsa-Putra, 2003: 22).

Ada beberapa asumsi yang menjadi dasar analisis transaksional ini. Pertama, mereka yang terlibat dalam transaksi-sadar atau tidak-selalu mempunyai pilihan-pilihan dan kemudian membuat keputusan. Kedua, pilihan dan keputusan ini didasarkan pada suatu rasionalitas yang berada dalam suatu Vol. 1, No. 1, Januari-Juni 2018 p-ISSN: 2654-6612 e-ISSN 2656-0798 
bingkai budaya tertentu. Rasionalitas di sini diartikan sebagai "cultural conception of the most efficient organization of means to ends in social action" (Parkin, 1976: 165 via Ahimsa-Putra, 2003). Konsep rasionalitas ini memperlihatkan adanya asumsi ketiga, yakni bahwa para pelaku menghadapi dan memiliki objek-objek yang bernilai (object of value), baik material maupun non material. Kemudian mereka (orang Sasak) menentukan pilihan dan membuat keputusan berkenaan dengan objek-objek tersebut hal itu menunjukkan asumsi yang keempat, yaitu objek-objek ini terbatas jumlahnya atau relatif jarang, sehingga para pelaku di situ terlibat dalam suatu zero-sum game (Ahimsa-Putra, 2003).

Asumsi-asumsi di atas dengan jelas memperlihatkan bahwa pendekatan transaksional, interaksional, sangat banyak bersentuhan dengan paradigma keputusan. Perbedaannya adalah pada aspek yang diperlihatkan pada isi pertukaran atau interaksi antarpelaku, pendekatan keputusan lebih memperlihatkan proses atau langkah-langkah pengambilan keputusan, penentuan pilihan (Ahimsa-Putra, 2003: 23).

Sebagai bentuk konkrit trasaksionalisme orang Sasak dapat kita temukan pada prosesi merariq yang didalamnya terdapat beberapa rangkaian prosesi seperti sorong serah ajikrama yang kita jadikan-obyek-dalam "pertukaran sosial". Sehingga dalam prosesi sorong serah ajikrama orang Sasak ini merupakan transaksi pengikat kekerabatan antara keluarga calon pengantin laki-laki dan keluarga calon pengantin perempuan.

Transaksi pengikat kekerabatan yang dilakukan oleh kedua belah pihak antara calon pengantin laki-laki dan perempuanyang nantinya-akan terjadi pengakuan secara sosial. Sadar atau tidak, orang sasak sudah melakukan hal yang sangat terstruktur dalam pertukaran sosial yang tingkatan aplikasinya dalam "transaksional".

\section{Struktural Pemikiran Orang Sasak}

Dalam wujud pertukaran sosial yang bersifat kolektif pada dasarnya berawal dari pemikiran Marcell Mauss tentang The Gift, 
pemberian, (1954). Pemikiran ini kemudian berhasil dikembangkan oleh Lévi-Strauss menjadi sebuah paradigma yang mampu membuat peneliti memahami begitu banyak fenomena kebudayaan secara komprehensif, karena digunakannya modelmodel di situ. Dengan menggunakan konsep pertukaran sebagai basisnya, Lévi-Strauss (1969) membangun model-model-yang tidak lain adalah struktur-struktur yang dibuat oleh antropologi untuk memahami aneka-ragam sistem kekerabatan dan pernikahan pada berbagai sukubangsa di dunia, khususnya lagi pada sukubangsa Sasak.

Pendekatan struktural yang disodorkan oleh Lévi-Strauss ini menggunakan beberapa asumsi dasar yang sangat jelas memperlihatkan pengaruh Marcell Mauss di situ. Asumsi yang pertama adalah bahwa dalam kehidupan manusia terdapat tiga macam "struktur", yakni: aturan sebagai aturan; resiprositas atau ketimbal-balikan (reciprocity); dan sifat mengikat dari pemberian (gift). Berkenaan dengan struktur yang pertama, Lévi-Strauss (1969) menjelaskan bahwa manusia pada dasarnya selalu mengisi kebebasan-kebebasan yang diberikan oleh alam dengan berbagai aturan. Dengan kata lain aturan sebagai sebagai aturan tersebut yang memang dibutuhkan oleh manusia, dan ini terlihat pada kebutuhan psikologis manusia. Manusia tidak dapat dihidup dalam kekacauan (chaos). Ia membutuhkan ketaraturan, karena itu ia selalu membuat aturan-aturan untuk perilaku. Selain itu, manusia juga 'menempelkan' ketertataan (order) pada kenyataan yang dilihatnya dengan cara melakukan klasifikasi. Klasifikasi ini pada dasarnya adalah juga aturan-aturan; aturan untuk 'menata' kenyataan yang dihadapi. Keberadaaan aturan sebagai aturan ini tidak disadari oleh manusia.

Mengenai struktur yang kedua, resiprositas, Lévi-Strauss mengatakan bahwa prinsip ini menunjukkan adanya oposisi antara Ego dan Alter. Prinsip ini tidak hanya bersifat umum, tetapi juga merupakan hasil dari 'struktur' tertentu yang ada dalam pikiran manusia, yaitu pola berfikir yang selalu membuat oposisi berpasangan (binary opposition). Dengan adanya prinsip Vol. 1, No. 1, Januari-Juni 2018 p-ISSN: 2654-6612 e-ISSN 2656-0798 
resiprositas tersebut terjadilah interaksi dalam kehidupan manusia. Dalam berhubungan dengan individu lain orang tahu bahwa resiprositas merupakan satu-satunya cara umum yang dapat diikuti agar bisa terjadi interaksi sosial, yang kemudian melahirkan masyarakat. Prinsip timbal-balik ini muncul secara spontan, dan terdapat juga dikalangan anak-anak kecil.

Struktur kedua tersebut kemudian menghasilkan struktur ketiga, yakni sifat mengikat dari pemberian. Melalui pemberian, yakni diberikannya suatu barang dari seseorang ke orang lain, terciptalah hubungan baru di antara pemberi dan penerima. Bahkan barang yang diberikan itu sendiri kemudian mendapat 'nilai' baru, sehingga tidak lagi sama dengan sebelumnya. Aktivitas saling memberi dalam kehidupan sehari-hari kemudian telah menciptakan dan menjaga hubungan-hubungan sosial yang ada. Menurut Lévi-Strauss struktur yang ketiga ini berada pada tataran yang berbeda dengan dua struktur yang ada. Kalau dua struktur petama berada pada tataran pemikiran manusia, struktur terakhir ini merupakan hasilnya. Meskipun demikian, struktur ketiga inilah yang paling penting perannya dalam penjelasan Lévi-Strauss mengenai sistem kekerabatan dan pernikahan.

Dengan demikian, menggunakan konsep pertukaran sebagai basisnya, Lévi-Strauss kemudian dapat memandang pernikahan (Sasak: merariq) sebagai suatu bentuk dari pertukaran alias komunikasi, dimana wanita menjadi sarana komunikasinya dan kelompok-kelompok kekerabatan merupakan unit-unit yang melakukan komunikasi tersebut. Agar suatu kelompok memperoleh kepastian dari mana dia akan mendapat wanita, ada dua bentuk pertukaran terbatas (restricted exchange) dan pertukaran meluas (generalized exchange), yang seringkali juga disebut sebagai pertukaran langsung dan tidak langsung (direct and indirect exchange) (Ahimsa-Putra, 2003).

\section{KESIMPULAN}

Sorong Serah merupakan tradisi turun temurun dari nenek moyang dan sudah melekat dalam masyarakat Sasak (bersifat 
aturan yang dipedomani), bahkan beberapa kalangan masyarakat baik itu tokoh agama dan tokoh masyarakat adat itu sendiri menyatakan bahwa jika tidak melaksanakan upacara adat ini akan menjadi aib bagi keluarga dan masyarakat setempat. Tradisi seperti ini berlaku hampir di seluruh lapisan masyarakat Sasak.

Sehingga, Sorong Serah Ajikrama ini juga merupakan gejalagejala sosial yang bentuknya "saling tukar menukar hadiah dan pemberian" yang tersebar luas dalam masyarakat Sasak, dan apa yang kita lihat dari gejala sosial tersebut ialah memperlihatkan pemahaman mengenai fungsinya dalam artikulasi keteraturan sosial, tentunya memiliki keterkaitan mengenai transaksionalisme dan strukturalisme.

Jadi, segala bentuk pemberian selalu dibarengi dengan sesuatu pemberian kembali atau imbalan. Dengan demikian, maka yang ada bukanlah hanya pemberian oleh seseorang kepada yang lainnya, tetapi suatu tukar-menukar pemberian yang dilakukan oleh dua orang atau kelompok yang saling memberi dan mengimbangi dalam Sorong Serah Ajikrama.

Sebagai bentuk konkrit trasaksionalisme orang Sasak dapat kita temukan pada prosesi merariq yang didalamnya terdapat beberapa rangkaian prosesi seperti sorong serah ajikrama yang kita jadikan-obyek-dalam "pertukaran sosial". Sehingga dalam prosesi sorong serah ajikrama orang Sasak ini merupakan transaksi pengikat kekerabatan antara keluarga calon pengantin laki-laki dan keluarga calon pengantin perempuan.

Dengan demikian, dalam transaksi sorong serah ajikrama sebagai pengikat kekerabat yang dilakukan oleh kedua belah pihak antara calon pengantin laki-laki dan perempuan-yang nantinya-akan terjadi pengakuan secara sosial. Sadar atau tidak, orang sasak sudah melakukan hal yang sangat terstruktur dalam pertukaran sosial yang tingkatan aplikasinya dalam "transaksional". 


\section{DAFTAR PUSTAKA}

Ahimsa-Putra, H.S.2003. "Dari Ekonomi Moral, Rasional, ke Politik Usaha" dalam Ekonomi Moral, Rasional dan Politik dalam Industri Kecil di Jawa, Ahimsa-Putra (ed.) Yogyakarta: Kepel Press bekerja sama dengan Yayasan Adikarya Ikapi dan Ford Foundation.

1978/ 1979.Adat dan Upacara Perkawinan Daerah Nusa Tenggara Barat, Jakarta: Proyek Penelitian dan Pencatatan Kebudayaan Daerah.

1983/ 1984. Upacara Tradisional dalam Kaitannya dengan Peristiwa Alam dan Kepercayaan di Nusa Tenggara Barat, Mataram: Proyek Inventarisasi dan Dokumentasi Kebudayaan Daerah Nusa Tenggara Barat.

1988.Sejarah Daerah Nusa Tenggara Barat, Jakarta: Proyek Inventarisasi dan Pembinaan Nilai Budaya.

2006. Strukturalisme Levi-Strauss, Mitos dan Karya Sastra, Yogyakarta: Kepel Press.

2007.Antropologi Struktural, (Terjemahan), Yogyakarta: Kreasi Wacana.

2007. Patron dan Klien di Sulawesi Selatan-Sebuah Kajian Fungsional-Struktural, Yogyakarta: KEPEL Press.

1991.Upacara Tradisinal Sorong serah dan Nyondol Dalam Adat Perkawinan Sasak di Lombok, Mataram: Proyek Inventarisasi dan Pembinaan Nilai-Nilai Budaya.

Geertz, C. 1992. Tafsir Kebudayaan, (Terjemahan), Yogyakarta: Kanisius.

Kumbara, A.A. N.A. 2008. Konstruksi Identitas Orang Sasak Di Lombok Timur, Nusa Tenggara Barat, Yogyakarta: Disertasi Pascasarjana Program Studi Antropologi UGM.

Levi-Strauss, C. 1966. The Savage Mind, Chicago: The University of Chicago Press.

Mauss, M. 1992. Pemberian: Bantuk dan Fungsi Pertukaran di Masyarakat Kuno, (Terjemahan: Parsudi Suparlan (ed.), Jakarta: Yayasan Obor Indonesia. 